\title{
Srdja Trifković*
}

\section{Оригинални научни рад}

UDK 316.75:323.1):28

\section{THE IMPACT OF ISLAM ON THE BOSNIAN PROBLEM}

The Myth of Harmonious Multiethnicity Revisited

Bosnia and Herzegovina was an Ottoman province from the time of the Ottoman conquest in 1463 until the Austrian-Hungarian occupation in 1878. During this period a large segment of the province's indigenous Slavic population was converted to the faith of their Turkish conquerors, often under duress, thus creating the westernmost outpost of Islam in Europe. In 1918 Bosnia and Herzegovina was incorporated into the newly created Yugoslav state following World War I, and eventually became one of Communist Yugoslavia's six constituent republics after World War II.

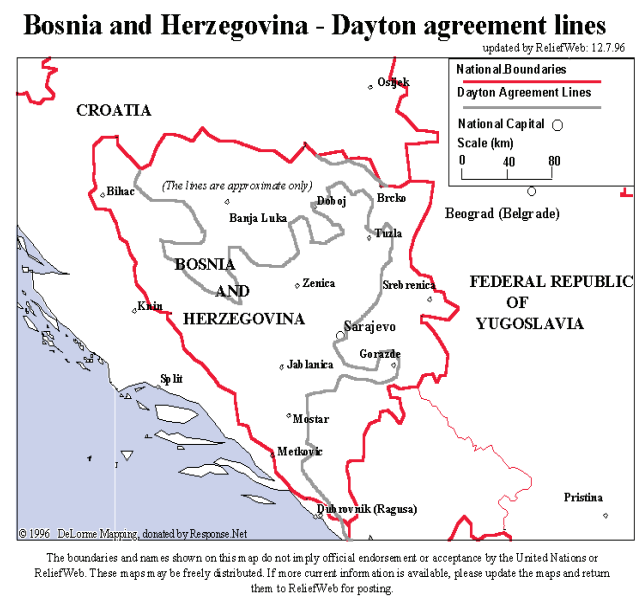

The defining feature of Bosnia and Herzegovina is the fact that it is not a nation-state, or even a multinational state, but a hybrid entity - in many ways a microcosm of the former Yugoslav federation itself. According to most recent estimates the Muslims ("Bosniaks") account for 48 percent of its approximately

* Dr. Trifković is Foreign Affairs Editor of Chronicles: A Magazine of American Culture and Visiting Professor of the University of Banja Luka. 
four million people, (Eastern Orthodox) Serbs for 37 percent, and (Roman Catholic) Croats for 14 percent. ${ }^{1}$ These three constituent nations co-exist in a single state but do not share the sense of common nationhood or common destiny.

Throughout its modern history Bosnia and Herzegovina has been an "ethnified" society and polity. Most Muslims support the model of a largely centralized, unitary state in which they would be the dominant community by virtue of their plurality. By contrast, the Serbs and Croats overwhelmingly owe their primary allegiance to their respective national communities centered on the neighboring kin-states.

The Islamist revival and activity in Bosnia and Herzegovina is the direct consequence of the three-sided war (1992-1995), the most violent segment of a series of conflicts that started when the Yugoslav Federation unraveled 1991. It chief cause was the determination of Alija Izetbegović, the late political leader of the Muslim community, that Bosnia should declare independence regardless of the will of other constituent nations, and regardless of risks associated with such approach. A year before the war started he declared, "I would sacrifice peace in order to win sovereignty for Bosnia," he said early in his presidency, "but for that peace in Bosnia, I would not sacrifice sovereignty"2

The ensuing conflict was a paradigmatic case of a "fault-line war" between Islam and non-Islam. ${ }^{3}$ The paradigm was defined two decades earlier by Izetbegović in his Islamic Declaration (1970). ${ }^{4}$ In this programmatic tract he denied the possibility of "peace or coexistence between the Islamic faith and non-Islamic societies and political institutions" and exalted the "natural function of the Islamic order to gather all Muslim communities throughout the world into one." He also asserted that "the Islamic movement should and can, take over political power as soon as it is morally and numerically so strong that it can not only overturn the existing non-Islamic power, but also build up a new Islamic one."5

Izetbegović's views were unremarkable from a traditional Islamic point of view: the final goal is Dar al Islam, where Muslims dominate and infidels submit. They were nevertheless deeply destabilizing in the Bosnian context. Of the three ethnic-religious parties in Bosnia and Herzegovina, Izetbegović's Muslim partythe SDA - was the most radical by far, in that it alone advocated a fundamental restructuring of the Bosnian society in accordance with a supposedly divine revelation. It attempted to do so not on Bosnia's own terms nor within its local

1 Central Intelligence Agency: The World Factbook. Washington DC: Directorate of Intelligence, 2011.

2 Izetbegović's obituary by David Binder in The New York Times, October 20, 2003

3 For an elaboration of Samuel Huntington's concept in the context of Southeastern Europe, see e.g. Christopher Deliso, The Coming Balkan Caliphate. Praeger, 2007.

4 For the full text of the Declaration in the language of its author, see: http://www.scribd.com/ doc/14683785/Islamska-deklaracija-Alija-Izetbegovi> Extracted July 5, 2012.

5 Circulated as a samizdat, the Declaration led in 1983 toIzetbegović's arrest and trial, with 12 others. He received a 14-year sentence but was released in 1988. 
paradigm, but within the terms of the global-historical process of the global Islamic renaissance. Izetbegović's successors in the Bosnian-Muslim political leadership in Sarajevo, headed by his son Bakir, have not given up that goal.

A key obstacle to the Islamists' long-term aspirations exists in the form of a complex constitutional arrangements codified in the Dayton Accords (November 1995) which formally ended the war. The Accords, mediated by the late Richard Holbrooke, were a compromise between the Muslim demand for Bosnia's sovereign statehood and the striving for self-rule by the other two communities. Combining federal and confederal elements, Bosnia and Herzegovina now has a weak central government, based in Sarajevo, and two self-governing "entities": the Republika Srpska ("Serb Republic," 49\% of B-H territory), the Muslim-Croat Federation of Bosnia and Herzegovina of equal size, and a small shared district in the northern town of Brčko. The elaborate ethnic power-sharing arrangements have the twin objectives of preventing the imposition of a centralist, unitary state by the Muslims, and preventing the secession of the Serbs and Croats.

Some Western advocates of B-H's unitarization have argued that a significant strengthening of the central government is necessary to overcome the legacy of ethnic divisions, to make the state more "multiethnic" and "multicultural." This view of Bosnia as a potentially harmonious melting pot ignores the historical experience and the current Islamist agenda of the Muslim leadership. It also begs an old dilemma: If Yugoslavia collapsed under the weight of differences among its constituent nations, how can Bosnia-Herzegovina develop and sustain the dynamics of a viable polity, let alone that of a centralized, unitary post-ethnic state? Richard Holbrooke provided the answer when he insisted that Bosnia and Herzegovina is, and has to be, structured as a federal state: "You cannot have a unitary government, because then the country would go back into fighting. That's the reason that the Dayton agreement has been probably the most successful peace agreement in the world in the last generation, because it recognized the reality."

Holbrooke was wrong on many Balkan issues, but on this particular one he was right. The future viability and stability of Bosnia and Herzegovina in general, and its ability to resist the surge of "Islamism" in particular, depend on the acceptance of that reality by the United States and America's key European NATO allies primarily Britain, France and Germany - who somewhat arrogantly call themselves "the international community."

THE FRUITS OF POLITICAL ISLAM - Not unlike Islamist parties elsewhere - notably the ruling Justice and Development Party (AKP) in Turkey - the leading Bosnian Muslim political party, the SDA, has had since its founding a public, "secular" front, and an inner core of Islamic cadres that made all key decisions. Accordingly, as the Bosnian crisis exploded in 1992 the SDA leadership claimed

6 "Holbrooke: Kosovo Independence Declaration Could Spark Crisis." CFR Interview, December 5, 2007. <http://www.cfr.org/kosovo/holbrooke-kosovo-independence-declarationcould-spark-crisis/p14968> Extracted July 5, 2012. 
for foreign consumption that it wanted to establish a multiethnic, liberal, democratic society; "but President Izetbegovic and his cabal [harbored] much different private intentions and goals." The Western media nevertheless proved eager - from an early stage of the war - to accept an idealized image of "Bosnia" as the Muslim side misrepresented it. With an appalling irony, the Muslims became identified with the victims, the Serbs with the Nazis. "Saving" the Muslims would expiate for not saving the Jews of Warsaw or Riga fifty years earlier.

On the other hand, within months of the war breaking out, Izetbegovic authorized the establishment of the El Moujahed brigade of the Bosnian-Muslim army (AbiH), composed of volunteers from all over the Islamic world. The unit was distinguished by its spectacular cruelty to Christians, including decapitation of prisoners to the chants of Allahu-akbar. ${ }^{9}$ El Moujahed was the nursery from which an international terrorist network spread to Europe and North America. As the 9/11 Commission Report notes, terror mastermind Khalid Sheikh Mohammed, along with three of the hijackers (Nawaf al Hazmi, Salem al Hazmi, and Khalid al Mihdhar), all fought in the Bosnian jihad.

The U.S. Administration of President Bill Clinton effectively acted as an ally of the Muslim side throughout the Bosnian war. In addition to showing the Europeans that they could not resolve the problem on their own, it appears that the decisionmakers in Washington were mistakenly hoping to improve America's standing in the Muslim world as a whole by helping Izetbegović. In 1996 the U.S. House Committee on International Relations launched an investigation into America's role in Iranian arms transfers to Croatia and Bosnia. Their investigation found that the Iranian government had provided the Bosnian Muslim Army (ABH) with two-thirds of its military hardware. According to their report,

Iran ordered senior members of its Iranian Revolutionary Guard Corps ("IRGC"), the elite force used to advance militant Islam, to travel to Bosnia to survey the military needs of the government. IRGC trainers taught the Muslims how to use anti-tank missiles and helped with troop logistics and weapons factories. The IRGC also incorporated religious indoctrination into military training. Iran used this leverage to urge Hizballah to send foreign fighters to the region as members of the Mujahideen. The effort was successful, and a force of thousands drawn from several pro-Iranian groups and other Islamic Opposition movements assembled in Bosnia. ${ }^{10}$

7 Lieutenant Colonel John E. Sray, USA. "Selling the Bosnia Myth to America: Buyer Beware." U.S. Army Foreign Military Studies Office, Fort Leavenworth, KS, October 1995

8 The region's once-thriving Jewish community was destroyed during World War II with the enthusiastic participation of two Muslim Waffen SS divisions, Hanjar (Bosnian) and Skenderbey (KosovoAlbanian).

9 Videos of such gruesome spectacles are circulated through Islamic centers and Internet sites in the West.

$10104^{\text {th }}$ Congress, $2^{\text {nd }}$ Session: Final Report of the Select Subcommittee to Investigate the United States Role in Iranian Arms Transfers to Croatia and Bosnia. Submitted: October 25, 1996. 
After the end of the Bosnian war, many foreign Jihadist volunteers remained in Bosnia and Heryegovina. ${ }^{11}$ The Bosnian-Muslim government circumvented the Dayton rules by granting the Mujahideen citizenship. Within months after the war's end they were well established, having taken over Serbian-owned properties and married local women. ${ }^{12}$ They included members of well-known terrorist organizations, such as al-Gama'a al-Islamiyya, Groupe Islamique Armée (GIA), Hamas and al-Qaida. The new citizens and other Bosnian veterans went on to perpetrate murder and mayhem all over the world. President Clinton was still in the White House when a classified State Department report warned that the Muslimcontrolled parts of Bosnia had morphed into a base for Islamic terrorism. ${ }^{13}$ It noted that hundreds of foreign mujaheddin who had become Bosnian citizens presented a major terrorist threat to Europe and the United States. Among them were hardcore terrorists, some with ties to bin Laden, but protected by the Bosnian-Muslim government. A confirmation came in November 2001 when two Bosnian passports were found in a house vacated in Kabul by the fleeing Taliban. ${ }^{14}$ The findings were summarized by a former State Department official: Bosnia had become "a staging area and safe haven" for terrorists.

An early sign came in March 1996. On the eve of a G-7 summit in Lille the French police discovered a plot to attack the Western leaders by a group of Muslims at nearby Roubaix who had fought in the Balkans. All of their weapons and explosives were smuggled from Bosnia. The French thus uncovered what they called "the Bosnian Connection." They also established that Osama Bin Laden's links to the Bosnian Muslims were known to the Clinton Administration, and quietly tolerated by Washington. ${ }^{16}$

The following year, the Bosnian Connection resurfaced following the bombing of the Al Khobar building in Riyadh: several suspects had served with the Bosnian Muslim forces and were linked to Osama Bin Laden. ${ }^{17}$ Abdelkader Mokhtari, an Algerian but also a Bosnian citizen, tried to help smuggle C-4 plastic explosives and blasting caps to a group plotting to destroy U.S. military installations in Germany. ${ }^{18}$ More notably, even the 9/11 attacks had a Bosnian Connection:

11 The Washington Post, November 30, 1995.

12 "Mujaheddin Remaining in Bosnia," The Washington Post, July 8, 1996.

13 The Los Angeles Times, October 7, 2001.

14 AP, November 21, 2001. As the Wall Street Journal Online noted on February 8, 2011, Osama Bin Laden received a Bosnian passport from the Bosnian embassy in Vienna in 1993.

15 "Le troisième membre du 'gang de Roubaix' se revendique proche du FIS." Le Monde, October 6, 2001.

16 L'Express, December 26, 1996. Three months later The Washington Post confirmed that "the Clinton Administration knew of the activities of Bin Laden's so-called Relief Agency, which was, in fact, funneling weapons and money into Bosnia."

17 The New York Times, June 26, 1997.

18 The Los Angeles Times, October 7, 2001. 
Khalid Sheikh Muhammad - the infamous KSM, the senior al-Qaida operative who planned the 9/11 attacks - was a seasoned veteran of the Bosnian jihad, as were two of the hijackers. It should be noted that the Millennium Plot at the end of December 1999, the narrowly averted al-Qaida attempt to blow up Los Angeles International Airport, was planned by a cell of mujahedeen operating in Montreal, most of them veterans of the Bosnian war, and the operation was controlled out of central Bosnia. ${ }^{19}$

Yossef Bodansky, director of the Task Force on Terrorism and Unconventional Warfare of the US Congress, has warned for years that Islamist terrorist network were thriving with the tacit connivance of the authorities in the Muslim-controlled regions. Bodansky specifically linked the central Zenica region north of Sarajevo with a series of suicide attacks in Baghdad in August 2003, including the bombing of the UN headquarters which killed 22 people. The cells were using Bosnia as a training ground and a gateway to send terrorists to Western Europe or to hide them on their way to the east if they were on the run. The local Bosnian-Muslim authorities, well aware of this, decided not to act. ${ }^{20}$ In fact, some terrorists for whom arrest warrants had been issued in the West go back to Bosnia where local liaison officers welcome them, provide accommodation and refuge until they are moved on to new assignments. ${ }^{21}$ The method of financing, unsurprisingly, rests on a network of a host of Saudi-finances "charities," compromized by terrorist links and under pressure elsewhere, but still active in the Balkans. Prominent among them was the Vazir in the Bosnian city of Travnik, the local ofshoot of the Al-Haramain Islamic Foundation, placed on the U.N. list of terrorist suspects in March 2002, whose officers were indicted in the United States in February 2005. ${ }^{22}$

A significant contemporary factor of Islamic radicalization in Bosnia is the growth of Wahabbism. Local security experts indicate that there are over 3,000 potentially dangerous individuals who follow the fundamentalist Salafite Islamic movement. One of their centers, at the northern Bosnian village of Gornja Maoča, was raided by 600 police officers in February 2010, but with slender results: the activists appear to have been warned by the Muslims in the Bosnian security apparatus of the pending action. In fact, the connivance of sympathetic local Muslims at different levels of officialdom has been and still remains the key obstacle to denying various Islamist extremists a foothold in B-H.

ISLAM AND SOCIETY - Understanding the complexities of contemporary Bosnia is not possible without some reference to the vastly different experience of the Ottoman Empire among its Muslims and non-Muslims. The denial of Turkey's

19 John Schindler, author of Unholy Terror, in the World Magazine, Vol. 22, No. 35, September 27, 2007.

20 Ibid.

21 “US expert believes Osama network active in Bosnia," AFP, October 25, 2004.

22 U.S. Attorney's Office, District of Oregon Press Release of February 17, 2005: "U.S. Branch of A1Haramain Islamic Foundation and Two Officers Indicted." 
ongoing re-Islamization goes hand in hand with an ongoing attempt by some Western authors to rehabilitate the Ottoman Empire and to present it as almost a precursor of Europe's contemporary multicultural tolerance and diversity.

Four salient features of Bosnia under the Ottoman rule were (1) institutionalized discrimination of non-Muslims; (2) personal insecurity of all its subjects, but primarily Christians; (3) an unfriendly coexistence of Muslims and non-Muslims; and (4) the absence of any unifying state ideology. It was a Hobbesian borderland with mosques. The Christians were subsequently subjected to the practice of devshirme. The annual "blood levy" of Christian boys in peacetime was a novelty even by the Arabian standards. This, the most hated of all taxes, necessitated deliberate mutilation of many healthy Christian boys by their parents to render them safe from capture. The practice has left a deep scar on the collective memory of the Bosnian Serbs. It has contributed to their thorough loathing of all aspects of the Ottoman legacy that persists to this day.

For as long as the Ottoman domain expanded, bringing new slaves and fresh tax revenue into the system, it could maintain the pretense of imperial glamor. After the death of Suleyman "the Magnificent" that expansion was finally checked and the decline started almost immediately. To survive the non-Muslims had to learn how to be obsequious to their masters and cautious with outsiders. At the same time the status of most non-Muslims, nominally regulated through the Millet system of selfgovernance, continued deteriorating with the decline of the Empire.

The local ruling elite in Bosnia was composed, overwhelmingly, of the descendents of local converts to Islam. Their behavior, remarkably reminiscent of the strident anti-Semitism of some former Jews (such as Karl Marx), displayed a suppressed guilt transformed into a grudge against their former co-religionists. In the $18^{\text {th }}$ and $19^{\text {th }}$ centuries the local Muslims asserted their rebellious independence $v i s-\grave{a}$-vis the Porte. This process was accompanied by far harsher treatment of the despised Christian rayyah than was either mandated or normally practiced from the Bosphorus. Avoiding the blood levy and improving one's overall material and social position were important factors affecting the decision to convert to Islam. This contributed to the new stratification of the Bosnian society under Ottoman rule, and created a new power balance among groups. The balance shifted drastically in favor of the converts. The emergence of a significant number of Islamized Slavs holding high posts in the Ottoman administration deepened the rift. Local Muslims, of the same blood and language as their subjects, started appearing as officials and tax collectors, often more brutal and arrogant than their Turkish predecessors. Bosnia's Muslims and non-Muslims, of the same ethnic stock but divided first by faith and then increasingly by culture, gradually became members of two deeply opposed social and political groups.

The converts' readiness to come to terms with the conquerors gave them an upper hand. This was the beginning of a tragic division, of separate roads for Bosnia's Muslims and Christians. The former became the rulers and the latter the ruled. In the 14th and 15th centuries the great majority of "Bosnians" were Christians, Orthodox 
or Roman Catholic in the north and west, predominately Orthodox in the south and east. In subsequent decades the phenomenon of Islamization, and all that it meant in terms of personal welfare and social advancement, eventually became the defining foundation of Bosnia's politics and society. The religious gap became the defining trait of subsequent ethnic identities. It fully shaped the inter-communal relations in the age of nationalism in the $19^{\text {th }}$ and $20^{\text {th }}$ centuries. The social realities were reflected at the level of religious affiliations. In the late $20^{\text {th }}$ century they were given contemporary political articulation in the writings and work of Alija Izetbegovic.

Izetbegović stepped down from power in 2000 and died three years later, but the mantle has been taken over by his son Bakir, who now leads the SDA party. Izetbegović-junior is an Islamist hard-liner par excellence whose followers have internalized his father's teaching and vision. They are active at all levels of Bosnia's Muslim political nomenklatura. As Jane's Intelligence Review concluded in 2006, "The current threat of terrorism in Bosnia and Herzegovina comes from a younger, post-war generation of militant Islamists, radicalized by US actions in Iraq and Afghanistan." This post-war generation has put on suits and ties, learned English, and perfected the art of taqiyya to a high degree. His counterpart in the religious establishment is the "Grand Mufti" of Bosnia (as he presents himself to the Western media), reis-ul-ulema Mustafa Cerić.

Far from being a "moderate," Cerić holds and espouses a variety of political views that are identical to those held by Islamic hard-liners in other countries. In a 2005 interview Cerić - a graduate of Cairo's Al-Azhar theological academy called Britain one of the early "trophies" of Islam in Europe. ${ }^{23}$ He counts among his international activities participation in radical Islamic groups and events, as well as links with Muslim activists banned from the U.S. for terrorist funding and phony Islamic "charities" tainted by terrorist links. ${ }^{24}$ After 9/11 Cerić was in the forefront of claiming "discrimination" when the U.S. authorities moved to close Bosnianconnected "charities" which were used as conduits of funds in support of Islamic terrorists.

Cerić's impact on the continuing inter-ethnic and inter-denominational tension in Bosnia and Herzegovina has been considerable. His statements are often controversial and sometimes so provocative that they appear calculated to outrage the two non-Muslim communities. He has declared today's Bosnia-which has a Christian, Serb and Croat majority! - a halfway house between the House of Islam (Dar al-Islam) and the House of War (Dar al-Harb). ${ }^{25}$ In this intermediate stage, known as Dar al-Sulh (the House of the Truce), Cerić admits that "Islam or the shariah cannot be implemented fully, but the government should endeavor to put

23 "Bosnia as launching pad for international terrorism: the Abdel Rahman - Bin Laden connection." February 21, 2005. <http://www.militantislammonitor.org/article/id/455> Extracted July 5, 2012.

24 “Muslim Aid 'charity' funds Al Qaeda \& sent Mujahideen to Bosnia." September 24, 2004. <http:// www.militantislammonitor.org/article/id/293> Extracted July 5, 2012.

25 "A Conversation with Dr. Mustafa Ceric." An interview with Nadeem Azam published in 2005. $<$ http://www.angelfire.com/hi/nazam/Aceric.html $>$. Extracted July 5, 2012. 
it into practice as much as possible... [I]t is unrealistic to expect us to implement shariah completely. That's what I want, of course, but it will not happen just like that."

Since Cerić wants the Islamic law implemented ("of course"), albeit less than completely at first, he has acted accordingly. In May 2011 he called for Sharia law to be incorporated into the Bosnian constitution while conducting Bosnia's first Sharia mass wedding in the city of Zenica. ${ }^{26}$ Almost two decades ago Cerić launched a campaign against mixed marriages and declared that children born to Muslim victims of rape were "easier to accept" than those born to Muslim women married to non-Muslim men. ${ }^{27}$ In May 2011 Cerić openly threatened a "Sarajevo Sumer," inspired by the uprisings in the Middle East and North Africa ("The Arab Spring), unless grades from religion classes were included in students' overall grade calculation. ${ }^{28}$ To the visiting Turkish prime minister he declared that Turkey "is our Mother, always has been and always will be." He advocates a ban on the sale of pork and alcohol in Sarajevo, and has suggested that Bosnian Muslims should "follow the example of the world's one billion Muslims and reject western secular society." 29

On "interfaith dialogue," in which he has been inordinately active, when he talks to his co-religionists Ceric privately admits that it is wrong to expect much from such forums. ${ }^{30}$ "Islam is the religion of God and it is the best way forward known to man. In it lies the salvation of humanity, dignity and all that is required for a creature to be classified as a human" (emphasis added). To view non-Muslims as not fully human, as Cerić does, is by no means extreme for a senior Islamic cleric: his position is based on the Islamic scripture, law, and historical practice. It should be noted that Bosnian Serbs and Croats agree on Cerić's dark wartime role. He is a named co-defendant in the 2009 lawsuit filed by the Croatia Libertas human rights center alleging murder and mistreatment of hundreds of Croat prisoners in Muslim camps. ${ }^{31}$ A year later, in April 2010, Cerić led prayers at the funeral of Bosnian Army General Rasim Delić. ${ }^{32}$ convicted of war crimes against Serbs and Croats by the International Criminal Tribunal for the former Yugoslavia (ICTY). ${ }^{33}$

26 "Bosnia: Muslim spiritual leader urges more Sharia law.” August 17, 2012. <http://www.adnkronos.com/AKI/English/Religion/?id=3.0.3666977693 > Extracted July 5, 2012.

27 David Campbell: National Deconstruction: Violence, Identity, and Justice in Bosnia. University of Minnesota Press, 1998, p. 112.

28 “Bosnian Muslim Leader Criticised Over Call for Protests." May 17, 2011. <http://www.balkaninsight.com/en/article/the-head-of-bosnia-s-islamic-community-accused-of-hate-speech $>$ Extracted July $5,2012$.

$29<$ http://www.allempires.com/forum/forum_posts.asp?TID=7410\&PN=2> Extracted July 5, 2012.

30 "A Conversation with Dr. Mustafa Ceric." An interview with Nadeem Azam published in 2005. $<$ http://www.angelfire.com/hi/nazam/Aceric.html >. Extracted July 5, 2012.

31 "Bosnian Croat NGO files war crimes suits against Muslim leaders." March 23, 2009. < http:// en.trend.az/regions/world/ocountries/1444323.html\#popupInfo> Extracted July 5, 2012.

32 “The Suicide Of Multiethnic Sarajevo?” April 25, 2010. www.rferl.org/content/The_Suicide_Of_ Multiethnic_Sarajevo/2023847.html?page=2> Extracted July 5, 2012. 
In 2005 Ceric told the BBC that in Europe "governments must essentially buy the trust of Muslims by institutionalizing their faith — giving it state sponsorship through schools, official bodies and so on." 34 He advocated the establishment of a pan-European representative Muslim body. "At a dinner to honour the [British] foreign guests who attended Mustafa Ceric's installation as Ra'is al-Ulama... Dr Ceric, remembered by many in Britain as the man whose discourse at the Muslim Parliament had reduced people to tears, (...) spoke brilliantly, totally at ease, free of constraints that the presence of non-Muslims had imposed elsewhere" [emphasis added]. ${ }^{35}$ Like all Islamic hard-liners parading as "moderates," Cerić has one message for the faithful and another for the "infidels."

ISLAM AND THE STATE - The rise and strengthening of the Islamist paradigm within the Bosnian-Muslim political and social elite centered in Sarajevo was not a temporary byproduct of the war. It can now be seen as its lasting result, with significant security implications. Eight years after Dayton, Germany's intelligence chief August Hanning described Bosnia and Herzegovina as "a hotbed of extremists ready to carry the fight of the Islamic terror syndicates against the 'godless West' to the southeast of Europe." 36 His concern was shared by the former commander of the NATO stabilization force in Bosnia (SFOR), Brig. Gen. Steven Schook, whose troops had monitored Islamist militants who fought alongside local Muslims. He described as one of his main tasks to prevent the ability of a terrorist organization to thrive in Bosnia. ${ }^{37}$

The task has been and still is beyond the outsiders' powers because of the nature of Sarajevo's political class. Far from being pro-Western, it is a key pillar of Turkey's current strategy and policy known as neo-Ottomanism. ${ }^{38}$ Iran is also seeking to exert a major influence in Bosnia. It had already obtained a foothold of its own when the Clinton Administration got Teheran's help in supplying the Muslim army with weapons. ${ }^{39}$ This was done in violation of the UN arms embargo initially demanded by the U.S. and behind the back of its European allies. ${ }^{40}$ It is remarkable that the Departments of State and Defense were not told at first of the arrangement. In the event, Iranian intelligence operatives came with the weapons. The result was the development of a symbiotic relationship between the ruling establishment in

\footnotetext{
$2015534 . \mathrm{html}>$ Extracted July 5, 2012.

${ }^{34}<$ http://news.bbc.co.uk/2/hi/uk_news/magazine/4283717.stm> Extracted July 5, 2012.

$35<$ http://www.militantislammonitor.org/article/id/455> Extracted July 5, 2012.

36 Der Spiegel, December 8, 2003.

37 "Foreign Islamists a concern for EU peacekeepers in Bosnia," AFP, November 29, 2004.

38 On neo-Ottomanism see Professor Darko Tanasković's masterly summary: Neo-Ottomanism, Doctrine and Foreign-Policy Practice (Neoosmanizam - doktrina i spoljnopolitička praksa, Beograd: Službeni glasnik, 2010).

39 "Clinton-Approved Iranian Arms Transfers Help Turn Bosnia into Militant Islamic Base," U.S. Senate Republican Policy Committee, January 16, 1997.

40 See "Fingerprints: Arms to Bosnia, the real story," The New Republic, October 28, 1996.
} 
Sarajevo and the Tehran regime. While meeting Sarajevo's representatives, to take a telling example, Akbar Hashemi Rafsanjani said that "the Jihad of the Bosnian and Palestinian nations is praiseworthy and a source of honor for Muslims" and added that "the resistance and faith of these nations will be registered in the history of Islam."

The Bosnian war was still raging when the late Sir Alfred Sherman, one-time advisor to Prime Ministers David Ben Gurion of Israel and Margaret Thatcher of Britain, warned that the Muslims' objective was to create a 'Green Corridor' in the heart of the Balkans, and that by supporting the Muslim side the West was "in effect fostering this Islamistan." ${ }^{2}$ Sherman's prescient diagnosis is confirmed by Col. Shaul Shay, an expert on Islam at BESA Center at Bar-Ilan University. Shay notes that "the Balkans serve as a forefront on European soil for Islamic terror organizations, which exploit this area to promote their activities in Western Europe, and other focal points worldwide." His conclusions are startling:

$[\mathrm{T}]$ he establishment of an independent Islamic territory including Bosnia, Kosovo and Albania along the Adriatic Coast, is one of the most prominent achievements of Islam since the siege of Vienna in 1683. Islamic penetration into Europe through the Balkans is one of the main achievements of Islam in the twentieth century. $^{43}$

John R. Schindler, professor of strategy at the U.S. Naval War College and former National Security Agency analyst, is another expert who insists that Bosnia provides the missing piece in the puzzle of al-Qa'ida's transformation from an isolated fighting force into a lethal global threat. ${ }^{44}$ Like Afghanistan in the 1980s, Bosnia in the 1990s became a training ground for the mujahidin, Schindler argues, leading to a blowback of epic proportions.

Seventeen years after the Bosnian war ended at Dayton, it remains misrepresented by the Western mainstream media. The American public is still unaware that hard-core Islamists have used Bosnia as a base for terrorist operations worldwide, including attacks on the United States from the Millennium Plot to 9/11, and that multinational veterans of the Bosnian jihad have conducted terrorist attacks around the world. This would not have been possible if the Clinton administration, in collaboration with Iran, had not secretly supplied Bosnia's "muj" with millions of dollars of weapons. ${ }^{45}$ The result of Clinton's Balkan policy is the establishment

\footnotetext{
41 “Iran, Bosnia to Exapnd Ties.” IRIB (Islamic Republic of Iran Broadcasting), December 21, 2003.

42 Sir Alfred Sherman: "Let's Remove the Blinkers." The Jewish Chronicle (London), September 30, 1994.

43 Shaul Shay, Islamic Terror and the Balkans. Transaction Publishers, 2008.

44 John R. Schindler, Unholy Terror: Bosnia, Al-Qa'ida, and the Rise of Global Jihad. Zenith Press, 2007.

45 “Clinton-Approved Iranian Arms Transfers Help Turn Bosnia into Militant Islamic Base,” U.S. Senate Republican Policy Committee, January 16, 1997.
} 
of a vibrant, resilient jihadist base in the Balkans. ${ }^{46}$ The collusion between Muslim terrorist groups and criminal gangs in the region has now reached a mature stage. ${ }^{47}$ It has spawned a transnational criminal network with jihadist sympathies. ${ }^{48}$ That network currently supplies Western Europe with thousands of smuggled humans (most of them Muslims) and with the bulk of its heroin, mostly of Afghan origin. ${ }^{49}$

The growing gap between the reality of Islam in the Balkans and Western mainstream narrative about its allegedly moderate and tolerant nature is by now too obvious to remain unchallenged. ${ }^{50} \mathrm{~A}$ leading Israeli authority on Islamic movements has summarized the problem succinctly:

In Bosnia it was the revivalist Islamic ideology of Izetbegovic ... was aided by Iran and other Muslim countries, happy to see Islamic politics back in Central Europe. Then came the Albanian uprising in Kosovo, which duplicated the same situation and drove the re-Islamization of that land under the support of the West. The result is that while the Muslims have established a continuity which drives a wedge within Christian Central Europe, the West is looking with indifference at that evolving situation which they hope will create a docile Turkish-like Islam. In view of the trouble Turkey itself is suffering from Muslim fundamentalists, it is doubtful whether these hopes will be fulfilled. ${ }^{51}$

Effectively helping "the establishment of a continuity which drives a wedge" in the heart of Europe has been a key theme of American policy-making in the region since 1992. The involvement of successive U.S. administrations in the Balkans illustrates the failed expectation that satisfying Muslim ambitions in a secondary theater will improve the U.S. standing in the Muslim world as a whole. The policy has never yielded any dividends, but repeated failure only prompts its advocates to redouble their efforts.

The problematic legacy of the Bosnian war - not only for the Balkans but for Europe as a whole and for the rest of the world - will not be resolved without critical reexamination of Western policies and Western illusions. Appeasing global jihad, in Bosnia or anywhere else, is not only morally unsupportable. It is also counterproductive in countering the existential threat of global terrorism. It is worse than a crime, it is a mistake.

\footnotetext{
46 "Foreign Islamists a concern for EU peacekeepers in Bosnia," AFP, November 29, 2004.

47 “Terrorists use Balkan corridor." IHT, April 18, 2006.

48 Less than a year after NATO intervention, on 10 March 2000, the UN human rights rapporteur Jiri Dienstbier declared that "Kosovo is in chaos," having become "a mafia paradise." Reuters, 20 March 2000.

49 National Criminal Intelligence Service: Western Balkan organised crime NCIS assessment November 2002; http://www.ncis.co.uk/ukta/2002/threat04.asp

50 "Fissures in Balkan Islam," Christian Science Monitor, February 14, 2006.

51 Raphael Israeli: From Bosnia To Kosovo: The Re-Islamization Of The Balkans. Ariel Center for Policy Research, Policy Paper No. 109, 2004.
} 